\title{
ANALYSIS OF CASH, DEBT AND PROFITABILITY AT PT. PERKEBUNAN NUSANTARA III (PERSERO) MEDAN
}

\author{
Umi Kalsum ${ }^{1}$, Salman Farisi' ${ }^{2}$, Muslim ${ }^{3}$, Winda Meliandani ${ }^{4}$ \\ ${ }^{1,2,3,4}$ Faculty of Economics and Business, Universitas Muhammadiyah Sumatera Utara \\ E-mail: umikalsum@umsu.ac.id
}

\begin{abstract}
The purpose of this study was to determine and analyze cash, debt and profitability at PT. Perkebunan Nusantara III (Persero) Medan period 2013-2018. This research method uses a descriptive approach with primary and secondary data sources. The data collection technique in this study used a documentation study. The results showed that cash and debt were not optimal in increasing the profitability of ROI (return on investment) and ROE (return on equity). Where cash has decreased every year because the company does not contribute to the company's wealth (profit) to cash which is feared that cash will not be able to finance its debts.PT. Perkebunan Nusantara III Medan in 2013-2018 experienced a significant increase, where the increasing debt will affect the company's profitability.
\end{abstract}

Keywords: Cash, Debt, and Profitability

\section{INTRODUCTION}

With the development of today's business world, every company must have the ability to compete with other companies in achieving the goals that have been set. Good management is not only needed to be successful in facing competition in the business world, but also so that companies can spend economically, this is closely related to the goal of every company, namely to generate profits or profits. Profit or profit is the most important for the survival of the company. The higher the company in achieving profit, the stronger the company in facing competition in the future.Kas is a current asset with the highest level of liquidity, meaning that with sufficient cash availability, the company will have no difficulty in paying short-term obligations. Because if the amount of cash owned by the company is getting bigger, the liquidity will be higher. Cash becomes so important because individuals, companies and even governments must maintain liquidity. Paying obligations as they fall due so that the activities concerned can continue to run.Under certain conditions the company can meet its funding needs by prioritizing internal sources of funds, but the company's growth will result in greater funding needs, so that in meeting funding sources the company can use sources of funds from outside the company, namely debt. Debt is all the company's financial obligations to other parties that have not been fulfilled, where this debt is a source of funds or company capital originating from creditors (Munawir, 2017).

PerThe development of a company is focused on how the company achieves its main goal, namely the achievement of predetermined corporate profits. The size of the profit or profit obtained by the company is a measure of the company's success in managing its business, besides that profit is also used by management in making decisions. 
Analysis of Cash, Debt and Profitability at PT. Perkebunan Nusantara III (PERSERO) Medan Umi Kalsum, Salman Farisi, Muslim, Winda Meliandani

\section{LITERATURE REVIEW}

\section{Understanding Profitability Ratios}

Profitability is a description of the company's management performance in managing the company. The use of profitability ratios is done by comparing the components in the financial statements, especially the statement of financial position and the company's income statement. There are many definitions of profitability put forward by experts, some of which the author will mention to find out the definition of profitability itself.

Pprofitability is showing the company's ability to generate profits during a certain period. The profitability of a company is measured by the company's success and the ability to use its assets productively, thus the company's profitability can be known by comparing the profits earned in a period with the total assets or capital of the company (Munawir, 2011).

Constellationo profitability is a ratio to assess the company's ability to seek profit or profit within a certain period. This ratio also provides a measure of the effectiveness of a company's management. This is indicated by the profit generated from sales and investment income. The point is that the use of this ratio shows the efficiency of the company (Kasmir, 2016).

\section{Types of Profitability Ratios}

StillEach type of profitability ratio is used to assess and measure the company's financial position in a certain period or for several periods.

typess profitability ratios include:

a) Gross Profit Margin

Gross Profit Marginmeis a ratio that measures the efficiency of controlling the cost of production or production costs, indicating the company's ability to produce efficiently (Sawir, 2009).

Gross Profit Margincalculated by the formula:

Profit Margin Gross $=\quad \frac{\text { Gross profit }}{\text { Income }} \times 100 \%$

\section{b) Net Profit Margin}

Net Profit Marginais the ratio used to show the company's ability to generate net profits. This ratio relates the net profit after tax with the net sales made by the company. The company's profitability is one way to accurately assess the extent of the rate of return that will be obtained from its investment activities. According to (Kasmir, 2016) Net profit margin is a measure of profit by comparing net income after interest and taxes compared to sales to see the company's net income on sales. Meanwhile, according to (Hani, 2015) Net Profit Margin is showing the company's ability to generate profits from a certain level of business volume. Net Profit Margin can be interpreted as a company's level of efficiency, namely the extent to which the company's ability to reduce costs. The higher the Net Profit Margin, the more effective a company is in carrying out its operations.

$$
\text { Net Profit Margin }=\frac{\text { Profit After Tax }}{\text { Income }} \times 100 \%
$$

\section{c) Return On Investment}

Return on investmentmeshow the ratio between net income after tax with total assets. Return on investment is a ratio that measures the company's overall ability to generate profits with the total amount of assets available within the company (Syamsuddin, 2009). 
Meanwhile, according to (Sutrisno, 2007) Return On Investment is the ability to be used to cover the investment issued.

$$
\text { Return On Investment }=\quad \frac{\text { Profit After Tax }}{\text { Total assets }} \times 100 \%
$$

\section{d) Return On Equity}

Return On Equity merthe return on equity or profitability of own capital is a ratio to measure net income after tax of own capital. The higher this ratio the better. This means that the position of the owner of the company is getting stronger, and vice versa (Kasmir, 2016). Return On Equity (ROE) is often also called business profitability is the ratio between the amount of profit available to owners of own capital on the one hand with the amount of own capital that generates profits on the other hand (Riyanto, 2001). Or in other words, it can be said that the profitability of its own capital is the ability of a company with its own capital to work in it to generate profits.

$$
\text { Return On Equity }=\quad \text { Net profit } \quad \text { Equity } \times 100 \%
$$

\section{Definition of Cash}

By Specifically, cash is said to be cash owned by a company that is recorded on the balance sheet in the current asset position. Cash in general is also defined as money that is deposited in a bank, which can be cashed out at any time. (Munawir, 2011) "Cash is cash that can be used to finance company operations. Included in the definition of cash are checks received from customers and deposited by the company in the Bank in the form of demand deposits or demand deposits, namely deposits in the Bank that can be taken back (using checks or bilyet giro) at any time required by the company".

\section{Definition of Debt}

Debts are all financial obligations of the company to other parties that have not been fulfilled, where this debt is a source of funds or company capital originating from creditors. Debt or company obligations can be divided into current debt (short-term debt) and long-term debt (Munawir, 2011). Mensequence (Ani Rahmaniar \& Soegijanto, 2016) Debt is an obligation to pay a certain amount of money at the agreed time. Mensequence (Hani, 2015) Debt is a claim from outside parties on current and future assets and resources owned by the company. It can be concluded that "Debt is a source of funds originating from third parties that must be returned at a mutually determined time." Men (Munawir, 2011) debts are grouped into:

1. Current debt or short-term debt

Current debtr is a company's financial obligation whose settlement or payment will be made in the short term (one year from the balance sheet date) using current assets owned by the company. Current liabilities include, among others:

a. Accounts payable, is a debt that arises from the purchase of merchandise on credit.

b. Notes payable are debts accompanied by a written promise (which is regulated by law) to pay a certain amount at a certain time in the future.

c. Taxes payable, both taxes for the company concerned and employee income taxes that have not been deposited into the State treasury.

d. costaccrued, are costs that have been incurred but have not yet been paid.

e. Long-term debt that will mature soon, is part (all) of long-term debt which has become short-term debt, because the payment must be made immediately.

f. Earningn received in advance (Deferred Revenue), is the receipt of advances for the sale of goods/services that have not been realized. 
Analysis of Cash, Debt and Profitability at PT. Perkebunan Nusantara III (PERSERO) Medan Umi Kalsum, Salman Farisi, Muslim, Winda Meliandani

2. Long term debt

Long-term debt is a financial obligation whose payment period (maturity) is still longterm (more than one year from the balance sheet date), which includes:
a. Bonds payable
b. Mortgage payable is debt that is secured by certain fixed assets.
c. Piother long-term benefits.

\section{RESEARCH METHOD}

Population and Sample

PeThe research approach used by the author is a descriptive approach. Sugiono (2008: p. 206). The place of this research was conducted at PT. Perkebunan Nusantara III (Persero) Medan. The type of data used in this study is in the form of document data in the form of financial reports (Balance Sheet and Profit and Loss) from 2013-2018, namely by studying, observing and analyzing documents related to the object of research.

SThe source of this research data is secondary data, namely data obtained directly from the source. The secondary data of this study were obtained from the Accounting department at PT. Perkebunan Nusantara III (Persero) Medan. According to Sugiyono (2002, p.129) "Secondary data is a source that does not directly provide data to data collectors, for example through other people or through documents". Secondary data is taken from data obtained from the company in the form of written data.

TeThe data collection technique used in this research is to use the documentation method. This method is done by searching, viewing and studying things in the form of notes and documents as well as recording written data that has to do with the object of research. The method of documentation in this study is to ask the company's financial statements.

TeThe data analysis technique of this research is by using descriptive analysis. Descriptive analysis is a data analysis technique that is carried out by collecting data, classifying data, explaining and analyzing so as to provide information and descriptions in accordance with the problems faced or researched.

\section{RESEARCH RESULT}

\section{Cash at PT. Perkebunan Nusantara III (Persero) Medan}

\begin{tabular}{cc} 
Year & Cash (Rp) \\
\hline 2013 & $1,454,138,126,456$ \\
\hline 2014 & $1,172,308,853,516$ \\
\hline 2015 & $827,081,535,887$ \\
\hline 2016 & $645,764,362,616$ \\
\hline 2017 & $938,198,472,534$ \\
\hline 2018 & $299,305,233,571$ \\
\hline Source of data: Financial statements of PT. Nusantara III Plantation
\end{tabular}

On the table above shows that in 2013 cash amounted to Rp.1,454,138,126,456, in 2014 cash decreased by Rp.1,172,308,853,516, in 2015 cash decreased by Rp.827,081,535,887, in 2016 cash decreased by Rp. 645,764,362,616, in 2017 cash increased by Rp. 938,198,472,534, and in 2018 it decreased by Rp. 299,305,233,571. 
Payable to PT. Perkebunan Nusantara III (Persero) Medan

\begin{tabular}{lc} 
Year & Total Debt $(\mathbf{R p )}$ \\
\hline 2013 & $6,187,277,307,525$ \\
\hline 2014 & $7,517,051,819,562$ \\
\hline 2015 & $8,223,094,474,394$ \\
\hline 2016 & $8,622,870,344,841$ \\
\hline 2017 & $11,230,196,506,592$ \\
\hline 2018 & $14,141,937,387,890$ \\
\hline
\end{tabular}

Source of data: Financial statements of PT. Nusantara III Plantation

The data above shows that the company's total debt has increased every year, in 2013 the total debt of Rp. 6,187,277,307,525, in 2014 amounted to Rp. 7,517,051,819,562, in 2015 amounted to Rp. 8,223,094,474,394, in 2016 of Rp. 8,622,870,344,841, in the year of Rp. $11,230,196,506,592$, in 2017 it was Rp. $11,230,196,506,592$, and in 2018 it was Rp.14,141,937,387,890.

The increase in total debt to the company is due to the company's increasingly rapid growth, resulting in greater need for funds in carrying out its operational activities.

\section{Profitability at PT. Perkebunan Nusantara III (Persero) Medan}

a. Return On Investment (ROI)

\begin{tabular}{ccccc} 
Year & $\begin{array}{c}\text { Profit after } \\
\text { Tax }(\mathrm{Rp})\end{array}$ & $\begin{array}{c}\text { Total Assets } \\
(\mathrm{Rp})\end{array}$ & $\begin{array}{c}\text { ROI } \\
(\%)\end{array}$ & $\begin{array}{c}\text { SOE Standard } \\
(\%)\end{array}$ \\
\hline 2013 & $396,777,055,383$ & $11,036,470,895,352$ & 3.60 & 18 \\
\hline 2014 & $571,825,378,563$ & $21,716,646,975,255$ & 2.63 & 18 \\
\hline 2015 & $596,372,459,810$ & $44,744,557,309,434$ & 1.33 & 18 \\
\hline 2016 & $911,999,643,578$ & $45,974,830,227,723$ & 1.98 & 18 \\
\hline 2017 & $1,229,464,178,674$ & $49,700,439,661,061$ & 2.47 & 18 \\
\hline 2018 & $1,266,743,456,939$ & $55,308,893,775,436$ & 2.29 & 18 \\
\hline
\end{tabular}

Sumber : Financial report of PT. Perkebunan Nusantara III (Persero) and boothfrom BUMN Kep. Men. Number : KEP-100/MBU/2002 (data processed)

The data above can be seen that in 2013 the company's profitability (return on investment) was $3.60 \%$. In 2014 it decreased by $0.97 \%$ to $2.63 \%$. In 2015 it again decreased by $1.3 \%$ to $1.33 \%$. In 2016 it increased by $0.65 \%$ to $1.98 \%$. In 2017 it again increased by $0.49 \%$ to $2.47 \%$. And in 2018 it decreased by $0.18 \%$ to $2.29 \%$.

\section{b. Return On Equity (ROE)}

\begin{tabular}{ccccc} 
Year & $\begin{array}{c}\text { Profit after } \\
\text { Tax }(\mathrm{Rp})\end{array}$ & $\begin{array}{c}\text { Total Equity } \\
(\mathrm{Rp})\end{array}$ & $\begin{array}{c}\text { ROE } \\
(\%)\end{array}$ & $\begin{array}{c}\text { SOE Standard } \\
(\%)\end{array}$ \\
\hline 2013 & $396,777,055,383$ & $4,849,193,587,827$ & 8.18 & 15 \\
\hline 2014 & $571,825,378,563$ & $14,199,595,155,692$ & 4.03 & 15 \\
\hline 2015 & $596,372,459,810$ & $36,521,462,835,040$ & 1.63 & 15 \\
\hline 2016 & $911,999,643,578$ & $37,351,959,882,882$ & 2.44 & 15 \\
\hline 2017 & $1,229,464,178,674$ & $38,470,243,154,469$ & 3.20 & 15 \\
\hline 2018 & $1,266,743,456,939$ & $41,166,956,387,546$ & 3.08 & 15 \\
\hline
\end{tabular}

Sumber : Financial report of PT. Perkebunan Nusantara III (Persero and boothfrom BUMN Kep. Men. Number : KEP-100/MBU/2002 (data processed) 
Analysis of Cash, Debt and Profitability at PT. Perkebunan Nusantara III (PERSERO) Medan Umi Kalsum, Salman Farisi, Muslim, Winda Meliandani

The data above can be seen that in 2013 the company's profitability (return on equity) was $8.18 \%$. In 2014 it decreased by $4.15 \%$ to $4.03 \%$. In 2015 it again decreased by $2.4 \%$ to $1.63 \%$. In 2016 there was an increase of $0.81 \%$ to $2.44 \%$. In 2017 it again increased by $0.76 \%$ to $3.20 \%$. And in 2018 it decreased by $0.12 \%$ to $3.08 \%$.

\section{DISCUSSION}

\section{Cash at PT. Nusantara III Plantation}

From the table above, cash and bank we can see that the company's cash from 2013, 2014, 2015, 2016 and 2018 experienced a very drastic decline and was categorized as poor, the company's cash decreased because the company did not contribute to the company's wealth (profit) to cash, while net income data shows an increase, where if this continues, it is feared that cash will not be able to finance its debts with cash. In addition, if the company is able to contribute its profits appropriately to cash, the company will be able to minimize income tax expenditures from the company. The increase in cash that occurred in 2017 was due to an increase in income received by the company. As for the decrease in cash that occurred from 2013 to 2016,

\section{Payable to PT. Nusantara III Plantation}

Utang is capital that comes from outside the company which is temporarily working in the company and for the company concerned it must be paid back in time (Riyanto, 2010:227). Therefore the company will try to find funds from outside by way of debt. Hilmi (2010) states that an increase in debt will affect the size of the profit for the company which reflects the company's ability to fulfill all its obligations, which is indicated by some part of its own capital used to pay all its obligations, because the more debt is used, the greater the obligation.

(Munawir, 2014), states that debt is all the company's financial obligations to other parties that have not been fulfilled, where this debt is a source of funds or company capital originating from creditors. Debt or company liabilities can be divided into long-term debt and short-term debt.

a. Hlong-term debt in increasing profitability

b. Meaccording to Nazia (2012) explained that long-term debt has a positive relationship with the existing ROA of the company, there is always an increase. The level of long-term debt will affect the level of ROA achieved by the company. If the costs incurred by the loan are less than the cost of own capital, then the source of funds originating from loans or debt will be more effective in generating profits, and vice versa. Short-term debt in increasing profitability

PeHassan's research (2016) states that short-term debt has a significant but negative effect on Return On Assets (ROA), the higher the debt in the company, the lower the profit generated. This research supports the pecking order theory which states that companies with high levels of profitability actually have relatively low debt levels, because companies with high profitability have abundant internal funds. This pecking order theory can also explain why companies that have higher levels of profit actually have relatively smaller debt levels. This study is also in accordance with the opinion (Kasmir, 2010), which states that if the ratio is high, it means that there is more funding with debt. it is difficult for the company to obtain additional loans because it is feared that the company will not be able to cover its debts with its assets. Likewise, if the ratio is low, the smaller the company is financed with debt. The results of the study are also in accordance with the pecking order theory which states that companies with high levels of profitability actually have relatively low debt levels, because companies with high profitability have abundant internal funds.

\section{Profitability at PT. Nusantara III Plantation}

From the table it can be seen that the ROI (Return On Investment) fluctuates (up - down) in the company's cash ratio which tends to be unstable. Based on the ROI (return on investment) profitability in 2013 to 2018 as measured by the SOE ratio standard, this ratio does not meet the percentage standard that has been set at $18 \%$. Thus, it can be concluded that the company's 
condition every year is considered not good because it is below the SOE standard, this shows the company has not been able to optimize its assets in generating profits. And ROE (Return On Equity) fluctuations (up - down) which tend to be unstable. Based on the ROE (return on equity) profitability in 2013 to 2018 as measured by the SOE ratio standard, this ratio does not meet the percentage standard that has been set at $15 \%$ so it can be concluded that PT. Perkebunan Nusantara III (Persero) is not able to achieve profitability standards (return on equity) every year or is unable to meet the company's ability to generate net profit using its own capital, so it can be concluded that the company cannot manage its own capital efficiently to earn income.

\section{CONCLUSION}

Kas has not been optimal in increasing the profitability of the companies studied. This conclusion is evident where in several years cash has decreased because the company does not contribute to the company's wealth (profit) to cash so that cash is unable to finance its debts.

Hdebt to PT. Perkebunan Nusantara III Medan in 2013-2018 experienced a significant increase due to an increase in the company's short-term debt and long-term debt. Debt that continues to increase will affect the level of profitability also has an impact on companies that will experience losses.

The occurrence of company profitability problems as measured by ROI (return on investment) and ROE (Return On Equity) in 2013-2018 has not reached the standards set by the Ministry of SOEs.

\section{REFERENCE}

Azhari, H. (2016). Analisa Laporan Keuangan Untuk Menilai Kinerja Keuangan Pada PT. Perkebunan IV Medan. Medan: UMSU.

Fahmi, I. (2011). Analisis Laporan Keuangan. Bandung: Alfabeta.

Gunawan, A. (2019). Analisis Kinerja Keuangan Pada Perusahaan Plastik Dan Kemasan Yang Terdaftar Di Bursa Efek Indonesia. Krisna: Kumpulan Riset Akuntansi, 10(2), 109-115.

Hani, S. (2015). Teknik Analisa Laporan Keuangan. Medan: UMSU Press.

Harahap, S. S. (2011). Analisis Kritis atas Laporan Keuangan. Jakarta: PT. Raja Grafindo Persada.

Hidayat, R., \& Parlindungan, R. (2018). Pengaruh Perputaran Kas Dan Perputaran Piutang Terhadap Return On Assets. Jurnal Riset Finansial Bisnis, 2(3), 123-134.

Jumingan. (2006). Analisis Laporan Keuangan. Jakarta: PT. Bumi Aksara.

Kasmir. (2016). Analisis Laporan Keuangan. Jakarta: PT. Raja Grafindo Persada.

Menteri, K. (2002). Keputusan Menteri Badan Usaha Milik Negara Nomor: KEP-100/MBU/2002. $1-26$.

Minanari, \& Susanti, A. Y. (2013). Analisa Rasio Profitabilitas Pada Koperasi Axa. Jurnal Lentera Akuntansi, 1(1), 140-155.

Mokodaser, M. J., Sabijono, H., \& Elim, I. (2015). Analisis Rasio Likuiditas, Leverage, Dan Profitabilitas Untuk Menilai Kinerja Keuangan Pada Perum Pegadaian Jakarta. Jurnal EMBA, 1(1), 136-144.

Mudawamah, S., Wijono, T., \& Hidayat, R. R. (2018). Analisis Rasio Keuangan Untuk Menilai Kinerja Keuangan Perusahaan Pada BUMN Yang Terdaftar Di BEI. Jurnal Administrasi Bisnis, 54(1), 20-29.

Munawir. (2011). Analisa Laporan Keuangan. Yogyakarta: PT. Liberty.

Muslih, M. (2019). Pengaruh Perputaran Kas Dan Likuiditas (Current Ratio) Terhadap Profitabilitas (Return On Asset). Krisna: Kumpulan Riset Akuntansi, 11(1), 47-59.

Panduan Penulisan Skripsi. (2015). Medan: Fakultas Ekonomi Universitas Muhammadiyah Sumatera Utara.

Putra, E., \& Sari, rindy antika. (2017). Analisis Manajemen Modal Kerja Dalam Meningkatkan 
Analysis of Cash, Debt and Profitability at PT. Perkebunan Nusantara III (PERSERO) Medan Umi Kalsum, Salman Farisi, Muslim, Winda Meliandani

Profitabilitas Pada PT. Perkebunan Nusantara III (Persero) Medan. Jurnal Riset Akuntansi Dan Bisnis, 17(1), 33-45.

Saragih, F. (2017). Analisis Rasio Profitabilitas Dalam Menilai Kinerja Keuangan Perusahaan PT. Pelabuhan Indonesia I (Persero) Medan. Kumpulan Jurnal Dosen UMSU, 57-68.

Sinta, I. ., Tambarta Kembaren, E. ., \& F, F. (2021). CONJUCTURE EFFECT OF OPERATIONAL COST FOR INCREASING FINANCIAL PERFORMANCE PT. GOTONG ROYONG JAYA. International Journal of Economic, Business, Accounting, Agriculture Management and Sharia Administration (IJEBAS), 1(1), 54-61. https://doi.org/10.54443/ijebas.v1i1.5

Sinta, I. ., Nur Ilham, R., Kumala Sari, D. ., M, M., Khaidir, K., \& Ekamaida, E. (2021). Training The Processing Of Tomato Sauce For A Home-Based Business The Scale Of SMES. IRPITAGE JOURNAL, 1(1), 26-28. https://doi.org/10.54443/irpitage.v1i1.24

Sawir, A. (2005). Analisis Kinerja Keuangan dan Perencanaan Perusahaan. Jakarta: Gramedia Pustaka Utama. 